\title{
QUESTIONING NEOENDOGENEITY: CASES OF COMMUNITY ECONOMIC DEVELOPMENT PRACTICE FROM ATLANTIC CANADA
}

\author{
Tamara Antonia Krawchenko \\ Organisation for Economic Cooperation and Development
}

\begin{abstract}
Neoendogenous approaches to community economic development have risen to prominence in recent years. The Organisation for Economic Cooperation and Development (OECD) has described such approaches as nothing less than "the new rural paradigm." But is this paradigm reflected in practice? This research examines the community economic development landscape_from the perspectives of federal and provincial funders to that of community-based groups-through two Atlantic Canadian case studies (Marystown, Newfoundland and Labrador, and Montague, Prince Edward Island). Governmental funders are found to prioritize economic and business development objectives above social, cultural, and community-oriented ones. These preferences shape the types of projects that are funded and the community groups that propel them, undermining the adoption of truly neoendogenous, community-driven practices.
\end{abstract}

\section{RÉSUMÉ}

Dans les dernières années, les approches néo-endogènes envers le développement économique communautaire ont cru en importance. L'Organisation de coopération et de développement économiques (OECD) a décrit ces approches comme entraînant ni plus ni moins qu'un « nouveau paradigme rural ». Mais la pratique reflète-t-elle ce paradigme? Cette étude examine le contexte pour le développement communautaire économique-du point de vue des subventionneurs fédéraux et provinciaux et de celui des groupes communautaires-au moyen de deux études de cas menées dans deux villes des provinces de l'Atlantique (c'est-à-dire Marystown, Terre-Neuve et Labrador, et Montague, Île-du-Prince-Édouard). II se trouve que les subventionneurs gouvernementaux donnent la priorité aux objectifs de développement économique et commercial aux dépens des objectifs sociaux, culturels et communautaires. Cette priorité a un impact sur les types de projets subventionnés et sur les groupes communautaires qui les appuient, entravant ainsi l'adoption de pratiques véritablement néo-endogènes dans les communautés.

KEYWORDS / MOTS CLÉS : Atlantic Canada; Community development; Economic development; Neoendogenous development; New rural paradigm / Canada atlantique; Développement communautaire; Développement économique; Développement néo-endogène; Nouveau paradigme rural 


\section{Krawchenko (2016)}

Community economic development in Atlantic Canada is small 'c,' 'big ' $E$,' and small 'd.' -Personal interview, project officer, Atlantic Canada Opportunities Agency, Anonymous,

\section{INTRODUCTION}

Over the past two decades a new paradigm for rural development has emerged-one that rejects aspatial, "topdown" industrial and sectoral development policies in favour of place-based, multi-sectoral, integrated development where communities and community-based actors have a strong role to play (Ambrosio-Albala \& Bastiaensen, 2010; Ellis \& Biggs, 2001; OECD, 2006, 2015, 2016; Shucksmith, 2010). This approach demands participatory development and explicitly values spatial planning, social attributes, cultural amenities, and the environment (Cabus \& Vanhaverbeke, 2003; Ray, 2001; Ward Atterton, Kim, Lowe, Phillipson, \& Thompson, 2005). It is an approach that recognizes something that community development practitioners have long argued: top-down development approaches "range from being weak to being outright failures since their policies and programs have not emerged out of the very fabric of the affected region" (Johnson, Hodgett, \& Royle, 2007, p. 28). In essence, meaningful community development requires the transformation of fundamental relations of power within a community, which is no small feat.

A host of scholarship has set out to theorize, describe, and analyze this "new rural paradigm," which is sometimes also referred to as "neo-endogenous development" (Ray, 1999, 2001). This article contributes to this body of literature by examining the community economic development landscape in two rural communitiesMarystown, Newfoundland and Labrador, and Montague, Prince Edward Island. It explores the relationship between local development groups and their government funders, including their operating environment; the pressures and constraints they face; the goals and values they wish to pursue; and the development objectives they prioritize. In doing so, relations of power that are so central to the local and community-based participatory intentions of the "new rural paradigm" are explored. This work is grounded in historical institutionalism with particular attention paid to the political economy of scale. Specifically it describes a situation where the structure of governmental funding places a heavy emphasis on economic and business development over community development. In this environment, projects focused on the latter are subsumed by priorities defined by governmental funding bodies, thus potentially placing constraints on truly endogenous forms of development.

This article is organized into four parts. First, the study is situated within the community economic development literature. This is followed by a description of the methods and theoretical framework. Next, the two community case studies are presented and finally, conclusions and recommendations for further study are offered.

\section{EMPHASIZING THE COMMUNITY IN ECONOMIC DEVELOPMENT}

The impetus to bring communities into economic development has come from many places. In Atlantic Canada, the Antigonish movement was highly formative in the 1930s in forwarding a system of cooperative economic institutions that were community led (Dodaro \& Pluta, 2012). In the 1960s, the rise of community power and social justice movements challenged established development practices (Harding, 1996, 2009; Magill \& Clark, 1975). It has also arisen from practices incorporated from the "developing" world, where the community scale is central due to the underdevelopment of state institutions (Pieterse, 1998; Stiglitz, 2002). It has been borne along with critique of technocratic and top-down forms of public administration-critiques that have been bolstered by increasing demands for more democratic and place-based policy making (Bradford, 2005). 


\section{Krawchenko (2016)}

Though there are diverse variants of community economic development (e.g., those who view economic success as a requirement for social well-being, in contrast to those who place poverty reduction and social exclusion as their focal point), common among them is a focus on endogenous development, where "genuine development is generated in a bottom up fashion, fuelled by the organization and mobilization of local communities" (Johnson, Hogett, \& Royle, 2007, p. 48). This is a fundamental basis for what the Organisation for Economic Cooperation and Development (OECD) (2006) has called the "new rural paradigm" and more recently the "Rural Policy 3.0"(OECD, 2016). In contrast, exogenous models focus on either bringing in the institutional factors required to create market-based opportunities (referred to as a state-led technocratic approach) or view growth as being led by dynamic centres to the exclusion of peripheral locales wherein a market-led (neoliberal) policy agenda is prescribed. Both of these exogenous takes on underdevelopment view the basic problem as a shortage of private-sector investment. Thus, supportive policies aim at lowering the cost of investment and supporting the labour market (in terms of competitive wages, supply, and skill set).

Neoendogenous variants of community economic development fundamentally entail changing "relations of domination" or reorienting power and agency to the local level (Bridger \& Luloff, 1999, p. 380). Such approaches are replete with such phrases as "devolution of decision-making authority to the local level" (Gibbs, 1994, pp. 106-107), "increased community self-reliance" (Rees \& Roseland, 1991, p. 17), and "localizing economic production and commerce" (Ernest Yanarella \& Richard Levine quoted in Bridger \& Luloff, 1999, p. 382). The literature in this area is diverse and variously describes the necessity for community resiliency, sustainability, agency, and capacity across economic, sociocultural, and environmental realms. This community-based case study suggests however that governmental funderswho are so instrumental in shaping local development priorities-do not treat these domains equally. While the language of "bottom-up development," community "resiliency," "capability," and "leadership" can be found in government policy documents (e.g., Government of Newfoundland and Labrador, 2013, p. 6; Government of Prince Edward Island, 2010, pp. 13, 15, 16), it is important to question whether this is in fact just "fashionable rhetoric," as Alan Barr (1995) has described in the Scottish experience. In attempting to unpack these different approaches, is it important to pay attention to "that way in which change is promoted who is promoting it, what legacy is expected to be left in communities and the extent to which communities may own that process and the outcome of change" (Noya, Clarence, \& Craig, 2009, p. 28). This study takes this approach by focusing on experiences of community economic practice through case studies grounded in local institutions, context, history, and experiences.

\section{THEORETICAL FRAMEWORK AND METHODS}

This project focuses on the meso-level-bridging the macro or national/provincial and micro or community levels. This work is grounded in historical institutionalism as a way to understand the institutional strategies and policies adopted in the case study communities (Mahoney \& Thelen, 2010; March \& Olsen, 1989, 1995, 2006; Steinmo, 2001; Steinmo \& Thelen, 1992; Thelen, 1999, 2000, 2002, 2003). This framework emphasizes that institutions structure responses to socioeconomic change; that socioeconomic and cultural contexts are key to understanding actor behaviour and outcomes; and that historical processes shape present institutional configurations and socioeconomic contexts. This approach-with its emphasis on institutions, context, and history-offers a bridge between actor-centric and state-centric interpretations. This research also draws on the political economy of scale literature that explores how the scalar organization of political and economic life under capitalism is socially produced and periodically transformed (Brenner, 1998; Smith, 1993; Swyngedouw, 1997). Such attention helps to understand the relationships between local groups and their provincial and federal funders and the logics that carry and reproduce them. 


\section{Krawchenko (2016)}

This research entailed a case study of two rural communities: Marystown, Newfoundland, and Montague, PEI. The case studies included: i) a review of regional and community economic development theory and literature; ii) analysis of primary and secondary documents and grey literature (e.g., newspaper articles, including local community papers and blog posts about rural and community development); and iii) 23 semi-structured interviews with community leaders, government officials (federal, provincial, and municipal), community-based organizations, business owners, and academics in the field. These are not mutually exclusive groups-some business owners are also community leaders and involved in managing community-based organizations. To offer further breakdown: 10 federal and provincial government officials were interviewed (including those in regional offices); 11 members of community-based groups were interviewed; and 2 academics. The term community-based group is used here to account for a broader array of groups beyond nonprofits and charitable institutions, such as local chambers of commerce that forward local development projects (often in tandem with others). Field interviews were conducted between September 2012 and March 2013. Participants were identified and approached based on non-probability key informant and snowball sampling. Together, the document and interview analysis were used to map emerging strategies for community and economic development. Interviews were recorded and transcribed and participants had the ability to choose an anonymous and non-attributed interview or an attributed interview for which all published attributions would be cleared with the interviewee in advance through written consent.

The two case study communities were chosen by using 2006 Statistics Canada Census data to filter out characteristics/variables (e.g., population change, population density, industry composition) at two levels of geography (larger Census Districts and smaller Census Subdivisions) with consideration given to proximity to larger centres, industry composition, and local government organization. The primary rationale for this process

was to reduce bias in case selection. A second consideration was to choose communities with differing industrial composition and a large enough population to have a robust local community development landscape.

It is important to acknowledge the limitations of this work. This research captures perspectives of communitybased organizations and the governmental authorities that structure funding by focusing on but two communities in Atlantic Canada. While the trends evident in these cases are reinforced by other research on the voluntary sector and community-based organizations in Canada, the generalizability of these cases to Atlantic Canada is limited due to the specific community characteristics and dynamics of each place.

\section{COMMUNITY ECONOMIC DEVELOPMENT IN RURAL ATLANTIC CANADA: CASE STUDIES}

What does the institutional landscape of community economic development (CED) look like on the ground? How do community actors experience CED and how do they interact with other levels of government? What shapes the kinds of projects they pursue and how they work with each other? These are the questions that have propelled this research. Among the community groups interviewed, governments (both federal and provincial) were key partners in the development process, both in terms of the structure of funding and the expertise that they bring to bear. Emphasizing this point, in a 2009 program review of the Atlantic Canada Opportunities Agency's (ACOA) (2009) work in community development, program stakeholders reported, "without ACOA as a committed partner in community development projects, it would be virtually impossible to attract funding from other partners" (p. 3). But of course, this is because government agencies such as ACOA provide key resources to the sector. As such, the ways that they structure programs shapes the agenda of groups at the local level. 


\section{Krawchenko (2016)}

Over the duration of fieldwork for this project (2012-2014) the relationship between government funders and community groups was in flux. Funding was increasingly structured for smaller amounts with requirements for matching funds both from other levels of government and the groups themselves. Community economic development projects now require robust business models, clear evidence of long-term sustainability, and heightened reporting requirements. Government funding bodies want to see that the projects they fund are robust and successful. However, something may be lost in the process. Several interviewees noted that the priorities of governmental funders did not match up with community priorities and that the governments involved (provincial and federal) focus disproportionately on business development over social and cultural development objectives.

This section proceeds by first discussing the institutional landscape for community economic development in both Prince Edward Island (PEI) and Newfoundland and Labrador (NFL) followed by a discussion of each case study in turn. This information is based on a literature review, review of secondary documentation (e.g., government reports), and interviews with research participants.

\section{The institutional landscape}

Early development initiatives in the Atlantic Provinces prioritized exogenous models of development. However, there has been a shift over time toward a more endogenous approach. From the 1990s onward, there has been recognition of the importance of social and human capital to development, and agencies such as ACOA have been increasingly instrumental in supporting local businesses including social enterprises. In 1999, the federal department of Human Resources and Skills Development Canada (HRSDC) released The Community Development Handbook: A Tool to Develop Community Capacity, which exemplifies this approach. The handbook describes the following elements as critical to community capacity: "people who are willing to be involved; skills, knowledge and abilities; wellness and community health; ability to identify and access opportunities; motivation and the wherewithal to carry out initiatives; infrastructure, supportive institutions and physical resources; leadership and the structures needed for participation; economic and financial resources; and enabling policies and systems" (HRSDC, 1999, p. 10). This research project has focused in particular on the last point-policies and systems that are embedded in institutions at multiple scales and how they enable or constrain community capacity.

The federal government has long been a major presence in rural development in the Atlantic region with ACOA at the helm -a role that is changing. ACOA faced an $\$ 18$ million budget reduction over three years starting in 2012 and has since reorganized some of its programs (CBC News, 2012). ACOA eliminated funding for Regional Economic Development Organizations (REDOs) across Atlantic Canada, which played a major role in community capacity building (ACOA, 2009, p. ii). ${ }^{1}$ Accordingly, it will now take a more direct role in engaging with groups for funding. ACOA's $(2013,2014)$ most recent reports on plans and priorities indicate that the organization is focusing on economic competitiveness, productivity, business development, and, in coordination with Infrastructure Canada, on infrastructure investment. This is a shift from some of its previous activities, including funding for social enterprise. The emphasis of this funding matters greatly where community groups are asked to match funds from other levels of government for projects. The priorities that ACOA sets have major implications for group access to provincial funds, particularly through matching grants requirements.

In terms of CED funding and support, PEl has adopted a unique model that arose out of the provincial government's Rural Action Plan (Government of PEI, 2010). Upon forming a new government in 2007, the Liberals articulated a policy focus on rural development and a large, province-wide community consultation strategy was undertaken. These consultations resulted in the 2010 Rural Action Plan and set out a strategy for 


\section{Krawchenko (2016)}

rural development, including 40 action items. The plan entailed some reorganization: three rural action centres (and two satellite ones) were created in order to bring together a variety of community economic development and business supports under one roof, and the portfolio of "rural development" was added to the Department of Fisheries and Aquaculture (now the Department of Fisheries, Aquaculture and Rural Development [FARD]). The plan also moved some provincial departments to rural areas to spread employment benefits across the province. It is for this reason that FARD is located in Montague. The plan promised increased resources for "effective, bottom up" community-based development in rural regions. While all provincial departments are involved in some aspect of rural development, FARD's role is to provide "a rural lens that relates to rural Prince Edward Island policies and programs across government" (personal interview, December 6, 2012). Under the report's sixth goal of supporting community development and capacity building fall a number of smaller goals: the creation of community economic development investments funds; increasing access to development funds; facilitating access to data and statistics; enabling information sharing; creating local population strategies; investing in rural infrastructure; expanding the role of municipalities in rural development; and investing in rural jobs (Government of PEI, 2010). The Community Economic Development Funds allow businesses to receive personal income tax credits for their commitment to local community investment.

In the late 1990s, the Government of Newfoundland and Labrador (1998) announced a Strategic Social Plan (SSP). This signified a "community turn" in economic development and prioritized the bottom-up involvement of community actors, empowering them to be a part of the policy process. The strategy was, however, short-lived: implemented in 2000 and replaced in 2004, it was subsequently eliminated a year later. Nevertheless, it took a novel approach: it focused on empowering the voluntary and community sector to "pursue place-based solutions that encouraged collaborative governance" (Close, 2007, p. 1). In his assessment of the Strategic Social Plan, Close (2007) found that:

the SSP did not realize the hopes of its proponents and designers, i.e., generate evidencebased policies and programs to produce viable communities and sustainable regions. It did, however, show that securing those objectives will require more support, financial and administrative, than the Plan received; it tested a model for regional consultation that proved to need revision, and raised interesting questions about what might be needed if government were to engage the community-based, voluntary sector in a genuinely devolved system of governance. (p. 25)

The strategic plan secretariat has come to be replaced by the work of the rural secretariat, which has been absorbed into an Office of Public Engagement of the Provincial Government. The rural secretariat has established nine regional councils that are composed of cabinet-appointed community members (not representatives of organizations) who provide advice to government and conduct some of their own research (supported by secretariat staff). There are nine such councils in the province, one of which covers the Burin Peninsula, the site of our case study. The Regional Councils could be seen as a "shade of grey": they are citizens, but are cabinet appointed. They are meant to consult with local citizens, but this consultation is in the form of reporting upward to government. The CED landscape in Newfoundland is changing yet again as the regional economic development boards have lost their provincial and federal funding. Most, such as the Schooner Regional Development Association (SRDA), are closing their doors. The evolution of the present model is not entirely clear, but regionalism and collaborative forms of governance seem to be at the forefront of present machinations. 


\section{Krawchenko (2016)}

\section{Community case study: Montague, Prince Edward Island}

Montague is a regional centre in eastern PEI. Its main industries are fishing, farming, and tourism. While the town's population is small-a mere 1,895 in 2011 (and a land area of roughly three square kilometres) -it holds a draw for surrounding areas across Kings County and its flow of traffic and amenities reflect this. It has a small main street and several larger businesses, including two grocery stores and a large hardware store. The waterfront has been developed with a marina, park, and cafe. The town has seen slight population growth over the past few years, increasing 5.16 percent between 2006 and 2011 (Statistics Canada, 2011). However, this figure is deceiving since the functional community-those who live, work, and use the community's amenitiesis much larger than the town's jurisdiction of roughly three square kilometres. Similar to many rural Atlantic communities, Montague's population is older; it has a median age of 47.2 years (Statistics Canada, 2011).

The town has a resourceful community economic development sector that has implemented some major projects. A count of the number of the number of registered non-profit organizations and charities reveals Montague to have 39 entities (including a large number of faith organizations); this stands in contrast to the second case study, Marystown, where the figure is but nine. The CED landscape in Montague faces significant challenges. Foremost is access to long-term operational funding, the recruitment of volunteers, and demands for the professionalization of the sector, trends that are echoed in a 2011 report of the Community Foundation of PEl on capacity building in the third sector.

The changes within the sector are grounded in a further overarching shift-from community development toward economic development at the community level. It is an important distinction. Governmental funding programs (provincial and federal) tend to use the term "community economic development," but the economic component looms large over other considerations. In the words of the Deputy Minister for FARD:

We are trying to promote economic development projects and to get them to think about economic development rather than quality of life things. We have the Island Community Fund for gaps that aren't available through federal-provincial agreements. We reworked the mandate of it to focus on rural economic development. It is a struggle to get community groups to think about economic development. Its not hard for them to think about fixing community assets like fire halls and community halls. (Personal interview, Deputy Minister Richard Gallant, December 6, 2012)

Funding decisions reflect this reorientation with increasing demands for mixed revenue sources, sustainable business plans, and professional reporting and accounting practices. This means that the types of groups involved in community development are different than in the past. A member of the local Chamber of Commerce, has described the situation thus:

No one thinks about how to develop the village into the future. In essence-community development and strategic planning is being pushed from a place where you don't usually see it: the chamber of commerce. It's more of an American idea. (Personal interview, December 10, 2013)

This issue was discussed with economic development officer Amie Swallow MacDonald who at the time worked closely with community groups to help develop and fund projects. It was reported that there is less funding focused on the development of community assets and far more focused on economic development activities than in the past. One of the town's most successful projects-Artisans on Main-illustrates this point. Artisans 


\section{Krawchenko (2016)}

on Main is a cooperative enterprise of artists that have brought vitality to the town's downtown by reclaiming unused buildings. However, the local Chamber of Commerce conceived the project. It was created as a form of place-making and street revitalization and received some municipal and provincial support and funding. It is an example of community economic development, with the Chamber of Commerce as the key institutional actor driving the process.

Throughout the interviews the issue of capacity was repeatedly raised. All interviewees commented on the capacity of community groups to carry on existing activities. One economic development officer describes the changing environment thus:

When I look at the capacity of community groups to continue their process-we have seen a lot of change-provincial and federal funding is far less than it was. Greenwich National Park was a project worth millions and now we are struggling to get $\$ 200,000$ projects. We aren't seeing as many projects. Most of the groups are trying to handle what they have. They have already developed quite a bit. I think you'll see them struggle because the capacity is not necessarily there for them to handle much more. The declining and aging of the populating has been a major challenge as well. Government and society keeps expecting groups to continue-but if you continue to cut their resources, everything is harder for them. They lost the resource of the Regional Economic Development Authorities; funding is harder to come by; the application process is more complicated; they are required to have much stronger arguments for what they do. (Personal interview, economic development officer, December 6, 2012)

Associations and authorities such as the Surrey Harbour Authority and the local Chamber of Commerce have greater capacity because they have staff and resources. But for the voluntary and non-profit sector as a whole, there are major challenges: "The capacity of volunteers is dwindling just because the population is dwindling and they are getting tired-they have been doing things for years" (Personal interview, economic development officer, December 6, 2012).

This issue is well known and FARD has worked with the Rural Action Centre to create training programs for the voluntary sector (a similar capacity building program is offered in Newfoundland and Labrador). Training topics have included how to make greater use of technology to save time, how to raise awareness, and how to effectively chair and run board meetings. This training aims to professionalize the sector. Follow-up workshops are anticipated. One rural planning officer (of FARD) who was involved in the leadership development workshops commented:

We are losing our volunteer base and community capacity-time seems to be of the essence. We are looking at how we can get resources together and boards together to work efficiently across a variety of areas. (Personal interview, rural planning officer, FARD, December 6, 2012)

Literature on the voluntary and non-profit sector in Canada reinforces these statements. For example, Lynn Eakin and Heather Graham's 2009 report which interviewed 32 non-profits and charities found that they are under increasing strain, and that funding challenges and regulatory challenges lead to a "veritable maze that adds a huge administrative burden to already over-burdened organisations" (p. 2). A major issue raised by the report is a lack of engagement with the non-profit and charitable sector in reform processes. 


\section{Krawchenko (2016)}

\section{Community case study: Marystown, Newfoundland and Labrador}

Like Montague, Marystown is a regional centre. Its strategic location on the ice-free Bay of Mortimer has historically made it a centre for fishing and ship-building activities. Today it is a community under stress: two of the major fish processing plants in the region have closed, the groundfish fisheries have collapsed, and the local economy is transitioning toward shellfish, aquaculture, and the oil, gas, and mining sectors and support industries. It is thus a cyclical and seasonal economy. It is the regional centre of the Burin Peninsula and as such, has a range of amenities, services, and stores greater than one would expect given the population base, which was 4,181 in 2011-little changed from the previous census (Statistics Canada, 2011). Similarly to Montague, the community development landscape in Marystown is in flux. During the course of field research, the Schooner Regional Development Association (the Regional Development Association for the region) closed its doors. However, there are a number of other development associations operating in the region, such as the Placentia West Development Association (which has recently been working with the Department of Fisheries and Oceans to support the lobster industry) and the Fortune Bay Development Association (which is pursuing research to develop the nearby Gisborne Lake as an asset).

Community development groups in the Marystown area face the same pressures for stronger business cases and more diversified funding sources as seen in Montague. In the words of Newfoundland and Labrador Assistant Deputy Minister Bruce Gilbert, "the rural development department is now focused on business; it is not really focused on community development" (Personal interview, Bruce Gilbert, February 23, 2013). A major feature of CED in Marystown is that it takes place in an economy that is industrially focused. Accordingly, the scale and scope of projects that engage with the industrial sector tend to be larger and require land-use planning. The municipality has been critical here. Despite limited formal capacity, together with project funders such as ACOA, the municipality has conducted strategic planning exercises to reorient local development and take the most advantage of short-term industrial project work.

Similarly to Montague, there are pressures facing the CED sector to professionalize and to contribute a portion of its own revenues to projects. The restructuring of funding has an irreversible impact on CED groups. In the past, the Department of Innovation, Business and Rural Development (IBRD) would cover up to 25 percent of a project's cost while ACOA would fund up to 75 percent (Personal interview, March 1, 2013). Now, groups are expected to contribute 10 percent of their own funds, ACOA will contribute a maximum of 33 percent of the total project cost, and IBRD a maximum of 25 percent (Personal interview, March 1, 2013). This pushes groups to prioritize their own funds and related projects. In the words of ACOA project officer Jody Brushett:

I don't think that ACOA's vision has changed, but some of our program criteria have changed and we have raised the bar a little higher. We have become more in tune to how community economic and business growth work together and how municipalities need to be strongly involved in future successes. (Jody Brushett, personal interview, February 29, 2013)

Groups such as the Heritage Run Tourism Association (HRTA) (an association of tourist operators) have managed to thrive amid this changing structure, while others have not. Throughout our interviews, the HRTA was recognized as an involved community actor that has undertaken significant projects. In the words of economic development officer Trevor Bungay, "they are a good example of a rural group that has been and continues to be successful" (personal interview, March 1, 2013). The association has a significant presence-in cooperation with local municipalities, it has created scenic lookout spots along the roadways, has privately operated tourism information centres in three locations throughout the peninsula, and has developed tourism assets and guides. The creation of two full-time staff positions was critical to these achievements. In 2007, the 


\section{Krawchenko (2016)}

HRTA met with each of the five major towns on the peninsula to promote a regional project for museums. Together with the towns, it has established a capital levy for ongoing tourism projects (Personal interview, February 28, 2013). It has, developed a project to pool resources and coordinate the museums on the peninsula, leveraged money from the Department of Innovation, Trade (now Business) and Rural Development to create a tourism map brochure, and has assisted community groups to develop a regional ATV trail network.

\section{CONCLUSION}

Local development groups face distinct pressures. Their access to funding has shifted: funding tends to be for smaller amounts and projects increasingly require own-source revenue contributions and robust business and sustainability cases. ACOA's 2012 funding crunch was a major driver of these changes. Communities in Atlantic Canada are not alone in facing these shifts; research from across Canada, the United States, Australia, and Europe demonstrates similar trends (Eakin \& Graham, 2009; Ryser \& Halseth, 2014). Together, these factors push for professionalization within the sector, more collaborative and networked projects, greater funding diversity, and a strong business case tied to economic development objectives (as opposed to social and cultural ones).

As a response to these shifts there are two promising actions in the communities of study. The first is that nonprofit and voluntary groups are increasingly networking to share resources and knowledge and collaborate on projects. It is difficult for groups to create such networks and related opportunities on their own, and government support has been instrumental in supporting these efforts. Second, governmental departments and agencies are in some instances providing professional training and support for this sector to help it meet the challenges arising from the shifting funding landscape as well as broader pressures related to declining and aging membership and the over reliance on key leaders within organizations to get things done. Both PEI and NFL have delivered workshops and training for the non-profit and voluntary sector in this regard.

However, on the flip side, as the two case studies here have shown, there is also a shift in the types of groups involved in the community economic development sector and the types of projects that are taken up. In both communities, business groups have led the major community economic development projects in the area. In Montague, the chamber of commerce was seen as the most active and resourceful community group while in Marystown, this was the association of tourism operators. One could say that these groups are institutionally aligned to the priorities of governmental funders, contributing to their success. Where economic development priorities loom large over community development ones it raises questions about the potential for locally derived endogenous development. In the words of one senior NFL government official:

Community development used to be all the rage-now it is like, yeah whatever. It went from community development to economic development to regional economic development. It's patronizing and top down, if nothing else. (Personal interview, anonymous NFL provincial government official, February 25, 2013)

The term "community economic development" requires dissection. Peter Boothroyd and Craig Davis (1993) offer a three-part distinction between the different components of community economic development; where the "economy" is prioritized, the focus is on growth promotion; where "development" is prioritized, the focus is on structural change, and finally, where "community" is prioritized, the focus is on communalization (p. 230). In the cases at hand, there is a focus on growth promotion, and this seems out of step with neoendogenous approaches. Commenting on this, Dr. Robert Greenwood of Memorial University states: 


\section{Krawchenko (2016)}

At a time when the OECD and researchers and governments for the most part recognize that you need a holistic and integrated approach, with horizontal policy coordination, interdepartmental and intergovernmental strategies and governance that connect government with NGOs-but the driving force of how funding is allocated and how authority is delegated or not is going in exactly the opposite direction. (Personal interview, Dr. Robert Greenwood, February 28, 2013)

This research has laid bare inherent tensions between the various aims of the stakeholders. There are clear power asymmetries that are embedded in institutional relationships that constrain and shape the local level. Truly neo-endogenous development requires reconciling of these contradictions along with far more participatory and community-driven forms of development. There are many extensions to this avenue of research. For instance, comparative research might examine the European Union's LEADER approach or Quebec's rural policy, both of which devolve power to local community groups and valorize cultural and social outcomes alongside economic ones. Other research extensions may look at the consequences of heightened regulatory and reporting requirements for the non-profit and voluntary sectors and how this has impacted how and what they work on in order to ascertain changing practices in Canada (Eakin \& Graham, 2009).

\section{ACKNOWLEDGEMENTS}

I would like to thank the Atlantic Canada Opportunities Agency for supporting this research through the Atlantic Policy Research Initiative and my collaborator, Dr. Marguerite Cassin, Dalhousie University. I am grateful for the thoughtful comments of the peer reviewers and to J.J. McMurtry and Marilyn Bittman for their review.

\section{NOTE}

1. In PEI, ACOA funded 100 percent of the operating cost of REDOs (ACOA 2009).

\section{REFERENCES}

Ambrosio-Albala, M., \& Bastiaensen, J. (2010). The new territorial paradigm of rural development: Theoretical foundations from systems and institutional theories [Discussion paper]. Antwerp, BE: University of Antwerp, Institute of Development Policy and Management.

Atlantic Canada Opportunities Agency (ACOA). (2009). Evaluation of the Atlantic Canada Opportunities Agency Community Investment, Community Development Resources, Official Language Minority Communities and Aboriginal Communities Program Sub-Activities. Moncton, NB: Evaluation Unit Finance and Corporate Services Atlantic Canada Opportunities Agency. URL: http://www.acoaapeca.gc.ca/eng/Accountability/AuditsAndEvaluations/Pages/ACOACommunityDevelopmentEvaluation Page1.aspx [July 21, 2015].

Atlantic Canada Opportunities Agency (ACOA). (2013). Report on plans and priorities: 2013-2014. URL: http://www.acoa-apeca.gc.ca/eng/publications/ParliamentaryReports/Documents/2014\%20RPP\%20\%20MAIN\%20DOC \%20-\%20EN\%20v117\%20for\%20web\%20pdf\%20-\%20no\%20signatures.pdf [July 21, 2015].

Atlantic Canada Opportunities Agency (ACOA). (2014). Report on plans and priorities: 2014-2015. URL: http://www.acoa-apeca.gc.ca/eng/publications/ParliamentaryReports/Pages/RPP_2014-15_TOC.aspx [July 21, 2015].

Barr, A. (1995). Empowering communities-beyond fashionable rhetoric? Some reflections on Scottish experience. Community Development Journal, 30(2), 121-132. 


\section{Krawchenko (2016)}

Boothroyd, P., \& Davis, H. C. (1993). Community economic development: Three approaches. Journal of Planning Education and Research, 12(3), 230-240.

Bradford, N. (2005). Place-based public policy: Towards a new urban and community agenda for Canada. Canadian Policy Research Networks, Research Report F|51 Family Network. URL: http://www. cprn.org/documents/35238_en.pdf [July 21, 2015].

Brenner, N. (1998). Between fixity and motion: Accumulation, territorial organization and the historical geography of spatial scales. Environment and Planning D, 16, 459-482.

Brenner, N., Jessop, B., Jones, M., \& Macleod, G. (Eds.). (2008). State/space: A reader. Toronto, ON: Wiley.

Bridger, J.C., \& Luloff, A.E. (1999). Toward an interactional approach to sustainable community development. Journal of Rural Studies, 15(4), 377-387.

Cabus, P., \& Vanhaverbeke, W. (2003) Towards a neo-endogenous rural development model for the Flemish countryside. Paper presented at the Regional Studies Association International Conference, April 1215, 2003. Pisa, Italy.

CBC News. (2012, May 22). ACOA cuts regional development funding. URL: http://www.cbc.ca/news/politics Instory/2012/05/22/nb-acoa-funding-regional-economic.html [July 21, 2015].

Close, D. (2007). The Newfoundland and Labrador Strategic Social Plan: The life cycle of an innovative policy. St. John's, NL: Memorial University of Newfoundland.

Community Foundation of PEI. (2011). Building the Capacity of PEl's Third Sector: Summary Analysis and Recommendations. URL: http://www.cfpei.ca/building_capacity_report.pdf [July 21, 2015].

Dodaro, S., \& Pluta, L. (2012). The big picture: The Antigonish movement of eastern Nova Scotia. Montréal, QC: McGill-Queen's University Press.

Eakin, L. \& Graham, H. (2009). Canada's non-profit maze: a scan of legislation and regulation impacting revenue generation in the non-profit sector. Toronto, ON: Wellesley Institute.

Ellis, F., \& Biggs, S. (2001). Evolving themes in rural development 1950s-2000s. Development Policy Review, $19,437-448$.

Gibbs, D. (1994). Towards the sustainable city. Town Planning Review, 65(1), 99-109.

Government of Newfoundland and Labrador. (1998). People, partners and prosperity: A strategic social plan for Newfoundland and Labrador. St. John's, NL: Government of Newfoundland and Labrador.

Government of Newfoundland and Labrador. (2013). Annual Report 2012-13: Voluntary and Nonprofit Secretariat and Rural Secretariat. St. John's, NL: Government of Newfoundland and Labrador.

Government of Prince Edward Island. (2010). Rural action plan: A rural economic development strategy for Prince Edward Island. Charlottetown, PEl: Department of Fisheries, Aquaculture and Rural Development.

Harding, A. (1996). Is there a "new community power" and why should we need one? International Journal of Urban and Regional Research, 20(4), 637-655.

Harding, A. (2009). The history of community power. Theories of Urban Politics, 27-39.

Human Resources and Social Development Canada (HRSDC). (1999). The community development handbook: A tool to build community capacity. URL: http://ccednet-rcdec.ca/sites/ccednet-rcdec.ca/files/051-hrdccd_handbook.pdf [July 21, 2015].

Johnson, D., Hodgett, S., \& Royle, S. (2007). Doing development differently: Regional development on the Atlantic periphery. Sydney, NS: University of Cape Breton Press.

Mahoney, J., \& Thelen, K. (Eds.). (2010). Explaining institutional change: Ambiguity, agency and power. New York, NY: Cambridge University Press.

Magill, R.S., \& Clark, T.N. (1975). Community power and decision-making: Recent research and its policy implications. The Social Service Review, 49(1), 33-45.

March J.G., \& Olsen, J.P. (1989). Rediscovering institutions. New York, NY: Free Press. 


\section{Krawchenko (2016)}

March J.G., \& Olsen, J.P. (1995). Democratic governance. New York, NY: Free Press.

March J.G., \& Olsen, J.P. (2006). Elaborating the "new institutionalism." In R.A.W. Rhodes, S.A. Binder, \& B.A. Rockman (Eds), The Oxford handbook of political institutions (pp. 3-20). Oxford, UK: Oxford University Press.

McMaster, R.B., \& Shepphard, E. (2003). Scale and geographic inquiry: Nature, society and method. Toronto, ON: Wiley.

Noya, A., Clarence, E., \& Craig, G. (Eds.). (2009). Community capacity building: Creating a better future together. Local economic and employment development series. Paris, FR: Organisation for Economic Cooperation and Development.

Organisation for Economic Cooperation and Development (OECD). (2006). The new rural paradigm: Policies and governance. OECD Rural Policy Reviews. Paris, FR: OECD.

Organisation for Economic Cooperation and Development (OECD). (2015). New rural paradigm: Linking up for growth. Paris, FR: OECD.

Organisation for Economic Cooperation and Development (OECD). (2016). Rural Policy 3.0. OECD Regional Outlook 2016: Productive Regions for Inclusive Societies. Paris, FR: OECD.

Pieterse, J.N. (1998). My paradigm or yours? Alternative development, post-development, reflexive development. Development and Change, 29(2), 343-373.

Ray, C. (1999). Towards a meta-framework of endogenous development: repertoires, paths, democracy and rights. Sociologia Ruralis, 39(4), 521-537.

Ray, C. (2001). Culture economies: A perspective on local rural development in Europe. Newcastle upon Tyne, UK: Centre for Rural Economy.

Rees, W.E., \& Roseland, M. (1991). Sustainable communities: Planning for the 21st century. Plan Canada, $31(3), 15-26$.

Ryser, L., \& Halseth, G. (2014). On the edge in rural Canada: The changing capacity and role of the voluntary sector. Canadian Journal of Nonprofit and Social Economy Research, 5(1).

Shucksmith, M. (2010). Disintegrated rural development? Neo-endogenous rural development, planning and place-shaping in diffused power contexts. Sociologia ruralis, 50(1), 1-14.

Statistics Canada. (2011). Census. URL: http://www12.statcan.gc.ca/census-recensement/index-eng.cfm [July $21,2015]$.

Steinmo, S. (2001). The new institutionalism. In B. Clack \& J. Foweraker (Eds.), The encyclopedia of democratic thought. London, UK: Routledge.

Steinmo, S., Thelen, K., \& Longstreth, F., (Eds.). (1992). Structuring politics: Historical institutionalism in comparative analysis. New York, NY: Cambridge University Press.

Stiglitz, J.E. (2002). Participation and development: Perspectives from the comprehensive development paradigm. Review of Development Economics, 6(2), 163-182.

Swyngedouw, E. (1997). Excluding the other: The production of scale and scaled politics. Geographies of Economies, 167-176.

Thelen, K. (1999). Historical Institutionalism in Comparative Politics. Annual Review of political science 2, 369-414.

Thelen, K. (2000). Timing and temporality in the analysis of institutional evolution and change. Studies in American political development,14(Spring), 101-108.

Thelen, K. (2002). The explanatory power of historical institutionalism. Mayntz, Renate (Hg.): AkteureMechanismen-Modelle. Zur Theoriefähigkeit makro-sozialer Analysen. Frankfurt, New York, 91-107.

Thelen, K. (2003). How institutions evolve: Insights from comparative-historical analysis. In J. Mahoney \& D. Rueschemeyer (Eds.), Comparative historical analysis in the social sciences. New York, NY: Cambridge University Press. 
Ward, N., Atterton, J., Kim, T., Lowe, P., Phillipson, J., \& Thompson, N. (2005). Universities, the knowledge economy and "neo-endogenous rural development." Centre for Rural Economy Discussion, Paper Series No. 1.

Wilson-Forsberg, S. (2013). The adaptation of rural communities to socio-economic change: Theoretical insights from Atlantic Canada. Journal of Rural and Community Development, 8(1), 160-177.

\section{ABOUT THE AUTHOR / L'AUTEUR}

Tamara Antonia Krawchenko is an Economist/Policy Analyst in the Governance and Territorial Development Division at the Organisation for Economic Cooperation and Development in Paris. The views expressed herein are those of the author and do not necessarily reflect the views of the OECD or its member countries. Email: Tamara.Krawchenko@oecd.org. 